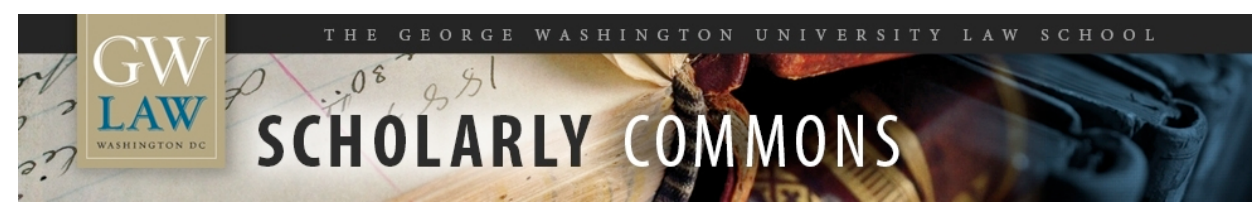

GW Law Faculty Publications \& Other Works

Faculty Scholarship

2013

\title{
Voice Identification Experts
}

Stephen A. Saltzburg

George Washington University Law School, ssaltz@law.gwu.edu

Follow this and additional works at: https://scholarship.law.gwu.edu/faculty_publications

Part of the Law Commons

\section{Recommended Citation}

Saltzburg, Stephen A., Voice Identification Experts (2013). 27 Crim. Just. (2013); GWU Law School Public Law Research Paper No. 2013-143; GWU Legal Studies Research Paper No. 2013-143. Available at SSRN: http://ssrn.com/abstract $=2663669$

This Article is brought to you for free and open access by the Faculty Scholarship at Scholarly Commons. It has been accepted for inclusion in GW Law Faculty Publications \& Other Works by an authorized administrator of Scholarly Commons. For more information, please contact spagel@law.gwu.edu. 


\section{Voice Identification Experts}

\section{BY STEPHEN A. SALTZBURG}

$\mathrm{T}$ The problems associated with eyewitness identification are well known. Examination of cases in which defendants who had been convicted but were later exonerated shows that mistaken eyewitness identification is one of the major contributors to wrongful convictions. Courts struggle with what to do about eyewitness identifications because prosecutions often cannot proceed without witnesses testifying to what they believe they saw and who they believe committed criminal acts. Should they instruct jurors on the dangers of mistaken eyewitness identification? Should they admit expert testimony on the dangers of mistaken eyewitness testimony? Should they rely exclusively on crossexamination to challenge the reliability of expert testimony? There is not yet a consensus on the best approach, although there are positive developments in certain police departments and prosecutor offices with respect to how photo arrays should be shown to witnesses. The issue does not go away, as illustrated by the Supreme Court's decision in Perry v. New Hampshire, 132 S. Ct. 716 (2012) (holding that due process does not require exclusion of suggestive identifications where there is no law enforcement responsibility for the suggestiveness).

An issue that is closely related to eyewitness testimony is voice identification, which might be called "earwitness identification." Should courts trust that jurors will be able to evaluate the reliability of such identification without some assistance from the judge or from expert witnesses? That is a question that arose in United States v. Schiro, 679 F.3d 521 (7th Cir. 2012).

\section{The Schiro Facts}

Five defendants were charged with a racketeering (RICO) conspiracy as a result of their involvement in the "Chicago Outfit," which the court described as a "long-running lineal descendant of Al Capone's

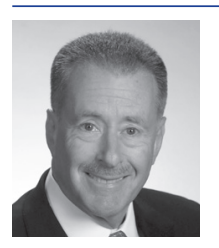

STEPHEN A. SALTZBURG is the Wallace and Beverley Woodbury University Professor at George Washington University School of Law in Washington, D.C. He is a past chair of the Criminal Justice Section and is a regular columnist for Criminal Justice magazine. He is also author of the book, Trial Tactics, Second Edition (American Bar Association 2009), an updated and expanded compilation of his columns. gang." (Id. at 524.) The Outfit conducted its operations through a series of "street crews." Two of the five defendants had been charged with and convicted of RICO conspiracy arising from their involvement with street crews. They argued unsuccessfully that they were placed in double jeopardy when they were charged with a RICO conspiracy for involvement in the Outfit given that the criminal activities of the Outfit and the crews were one and the same. The court concluded that while the street crews were operating divisions of the Outfit, the Outfit had powers and responsibilities that the crews did not have.

James Marcello, one of the defendants who lost his double jeopardy claim, raised an objection at trial and argued on appeal that the trial judge abused discretion in excluding expert testimony on the issue of voice identification. The majority described the evidence issue as follows:

Marcello raises an evidentiary issue. A victim's daughter identified Marcello's voice as that of the man who called her father on the day of the father's disappearance. Marcello wanted to present an expert witness who would testify that voice identifications are often mistaken. The judge excluded the evidence. He was skeptical about its empirical basis and also thought that the jury already had a good understanding of the fallibility of "earwitness" identification. We do not suggest that such expert evidence is worthless or that jurors always grasp the risk of misidentification inherent in eyewitness and earwitness testimony. But a trial judge has a responsibility to screen expert evidence for reliability and to determine the total effects of proposed evidence, weighing its probative value against its potential to (among other things) confuse the jury. See Fed. R. Evid. 403. Both reliability and potential for confusion were factors in this case and we cannot say the judge abused his discretion in refusing to admit the expert evidence, which the jury might have taken as a signal that it should disregard the witness's identification testimony. See United States v. Bartlett, 567 F.3d 901, 906 (7th Cir. 2009). If jurors are told merely that voice identifications frequently are mistaken, what are they to do with this information? The defendant's lawyer will argue mistaken identification and jurors told that such mistakes are common may be afraid to make their own judgment.

(Schiro, 679 F.3d at 529.)

A dissenting judge disagreed with the majority on the double jeopardy issue and had a very different take on the voice identification issue. She argued that Marcello's proposed expert testimony would have

Published in Criminal Justice Volume 27, Number 4, Winter 2013. (c) 2013 by the American Bar Association. Reproduced with permission. All rights reserved. This information or any portion thereof may not be copied or disseminated in any form or by any means or stored in an electronic database or retrieval system without the express written consent of the American Bar Association. 
done much more than simply tell the jury that voice identifications are often mistaken, and she described the background and the importance of the voice identification in more detail than did the majority.

Marcello was accused of murdering Michael Spilotro. Spilotro's daughter, Michelle, testified that on the day of her father's murder, a man called their home and asked to speak to him. She testified that the same person had regularly called her father. Three years after Spilotro's death, Michelle listened to a "voice lineup" put together by the FBI. The first five voices on the tape were those of officers reading a sample piece of text; the last was Marcello's. Michelle picked Marcello's voice as the one she remembered hearing on the day of her father's death. At trial, she told the jury that she was " 100 percent sure" it was Marcello's voice she had heard on the phone.

(Id. at 542 (Wood, J., dissenting).)

\section{The Expert Testimony}

Marcello sought to rely on Daniel Yarmey, a professor of psychology who had conducted extensive research on memory and who had paid particular attention to voice identification. The proposed expert testimony had two parts: it would have explained the reliability problems with voice identification, and it would have addressed specific issues relating to the FBI voice lineup.

Yarmey did not simply offer an opinion that voice identifications were often unreliable; he intended to point to specific studies in which misidentification rates were as high as 45 percent, and he was prepared to discuss the factors that affect the reliability of voice lineups. In addition, Yarmey was prepared to describe an empirical analysis of the FBI voice lineup that he conducted. In his experiment, he recruited 157 undergraduates at his university to listen to the lineup and to try to identify the suspect's voice using a number of factors. The students identified Marcello at a rate that exceeded pure chance. This suggested that the "samples" used by the FBI were not a neutral or reliable test of the daughter's ability to identify Marcello's voice, because students were identifying it more often than chance would predict even though they had no experience with the voice.

The trial judge excluded the proposed testimony, but not because of a concern about Yarmey's qualifications or the reliability of his testimony. Instead, the judge concluded that it was not necessary to assist the jury because the judge examined the voice lineup and found that there was "nothing about the difference [between Marcello's voice and the others] that would suggest to a hearer, to a listener, that one or the other was actually the suspect." (Id. at 543 (alteration in original).) Apparently, the judge thought the jury could make the same analysis without expert help.

\section{The Dissent's Concern}

The dissent was concerned about eyewitness testimony generally and the mounting evidence of its contribution toward erroneous convictions:

Even though our review of a district court's decision not to admit expert testimony is deferential, see United States v. Carter, 410 F.3d 942, 950 (7th Cir. 2005), in my view the district court's refusal to admit Dr. Yarmey's testimony was a mistake. In recent years, courts have become more aware of the reality that human memory is not necessarily reliable. A study of 200 wrongful convictions revealed that $79 \%$ rested in part on mistaken eyewitness identifications. Brandon L. Garrett, Judging Innocence, 108 Colum. L. Rev. 55, 60 (2008). This does not mean that courts must impose a blanket ban on such testimony, but it is critical to be cautious. We cannot ignore the power that a witness's claim to be " $100 \%$ sure" may have on a jury, nor can we ignore that such witnesses are sometimes, unfortunately, mistaken. The Supreme Court recently emphasized that one tool that courts can use to ensure juries do not give such testimony more weight than it is worth is to allow "expert testimony on the hazards of eyewitness identification." Perry $v$. New Hampshire, 132 S. Ct. 716, 729, 181 L. Ed. 2d 694 (2012). As Dr. Yarmey's research shows, a witness's voice memory is not exempt from the sort of problems that we more commonly associate with a witness's vision; just as with eyewitness identification, expert testimony on the reliability of voice identification reveals vulnerabilities that lie outside the range of common knowledge.

(Schiro, 679 F.3d at 543.)

The dissent cited a prior decision in which the court suggested that trial judges should not exclude expert testimony simply because jurors may appreciate that eyewitness testimony is fallible.

As we explained in United States v. Bartlett, expert testimony should not be kept out simply because a court believes "jurors know from their daily lives that memory is fallible." 567 F.3d 901, 906 (7th Cir. 2009). That may be true, but "[t]he question that social science can address is how fallible," id., and thus how deeply the jury might wish to discount any given identification. "That jurors have beliefs about this does not make expert

Published in Criminal Justice Volume 27, Number 4, Winter 2013. (c) 2013 by the American Bar Association. Reproduced with permission. All rights reserved. This information or any portion thereof may not be copied or disseminated in any form or by any means or stored in an electronic database or retrieval system without the express written consent of the American Bar Association. 
evidence irrelevant; to the contrary, it may make such evidence vital, for if jurors' beliefs are mistaken then they may reach incorrect conclusions. Expert evidence can help jurors evaluate whether their beliefs about the reliability of eyewitness testimony are correct." Id. (Schiro, 679 F.3d at 543.)

Finally, the dissent pointed out that the trial judge's opinion was inconsistent with the experiment that Dr. Yarmey conducted, which suggested that the judge might have been wrong and that jurors might similarly fail to appreciate problems with the voice lineup.

As is clear from the district court's remarks in this case, the court itself held beliefs about the reliability and suggestiveness of the voice lineup that are belied by the expert's conclusions. As far as we know, the jurors shared these misconceptions. This case thus highlights why it is critical for jurors to hear expert testimony in order to be able correctly to evaluate a witness's memory. Just because courts have routinely admitted laywitness identification in the past is no reason to continue to do so without skepticism, in light of modern research showing the fallibility of such identifications. When a court does admit such identification testimony, expert testimony will often be necessary to enable jurors to properly evaluate its reliability.

(Id. at 543-44.)

\section{Lessons}

Given the evidence that mistaken identification testimony has contributed to wrongful convictions, there is good reason for courts to seek ways to reduce the likelihood that jurors will treat such testimony as infallible and focus on the factors that tend to increase or decrease reliability. One way is to admit expert testimony that can educate jurors on these factors.

There also is some reason to believe that jurors may be uncertain as to whether voice identification is more reliable, less reliable, or similar in reliability to visual identification. Each reader can ask himself or herself this question: what do I know about the relative accuracy of ear and eye identifications? If the answer is "nothing," that answer would suggest the usefulness of expert testimony when any form of identification evidence is proffered.

But, the case for admitting some expert testimony does not necessarily mean that all such testimony should be admitted. There is a good argument in favor of testimony that does not purport to tell jurors how reliable particular testimony is and that focuses on factors that should usually be considered in assessing eyewitness accounts.
One part of Yarmey's testimony fits this description. But what about the experiment? The dissenting judge appeared to argue that the fact that the judge reached a different conclusion about the reliability of the voice lineup demonstrated the need for the jury to hear about the experiment. This argument failed to address, however, seven crucial words that the dissent used to describe the experiment in which the students listened to the FBI voice lineup: the students were asked to "evaluate it using a number of factors." What were those factors? The choice of factors identified for the students might have explained their more than random selection of Marcello's voice. Presumably, the daughter who made the identification was not given factors to consider. The question, then, is whether choice of factors can itself influence an identification.

Moreover, the daughter testified that she had heard the same voice on a number of prior occasions. Does the research indicate whether and to what extent repeated exposure to an individual or a voice may increase the ability to make an accurate identification? If so, would it be important to bring this information to the jury? If not, is there a danger that general testimony about identifications may fail to focus on an important factor?

These are questions that will be asked as identifications are challenged and expert testimony is offered. There should be no doubt that there is a place for expert testimony about identifications. Yarmey's testimony may serve as a reminder that a trial judge need not decide that proffered testimony must be either admitted or excluded in its entirety. A judge may decide that some portions of testimony provide useful background for jurors to consider while other portions raise questions about reliability.

Looking back at Yarmey's testimony, it seems clear that the majority may have exaggerated when it said that if the judge had admitted the testimony, "the jury might have taken [this] as a signal that it should disregard the witness's identification testimony." (Id. at 529 (majority opinion).) In fact, had the testimony been admitted, the jurors might have understood that Yarmey was simply educating the jurors on the fact that sometimes witnesses are wrong and that some identifications are more suggestive than jurors might realize. The jurors would have still been aware that the daughter had heard the voice on previous occasions. The answer to the majority's question, which was "[i]f jurors are told merely that voice identifications frequently are mistaken, what are they to do with this information?" (id.), is that jurors should not simply be told that voice identifications frequently are mistaken; instead they should be educated as to factors that promote or detract from accuracy, and they should carefully examine identification testimony. That does not seem like a bad thing. 